\title{
Thirteen Ways of Looking at A Blackbird: Deconstruction of Binary Opposition Between Imagination and Reality
}

\author{
SHI Xuan \\ Huashang College Guangdong University of Finance and Economics, Guangzhou, China
}

\begin{abstract}
Wallace Stevens is one of five greatest poets in America in 20th century. The relation between imagination and reality is a major theme of his poems. He holds the view that the mission of poets is to build a bridge linking the world of imagination and of reality with the result of deconstructing the logic of binary opposition since the time of Plato. Thirteen Ways of Looking at A Blackbird is a representative poem that expresses Wallace's thoughts of deconstruction. This article is to probe into how the poet establishes the reality dominated by imagination and then how he deconstructs the binary opposition between imagination and reality since the time of Plato.
\end{abstract}

Keywords: Wallace Stevens, imagination, reality, deconstruction, Thirteen Ways of Looking at A Blackbird

\section{Introduction}

Wallace Stevens is one of the most preeminent American poets in the 20th Century, and is widely honored as "poet of poets" or "poet of criics". Most of his poems, though short and concise, are abstract and ambiguous, "centering on one ultimate thinking - the relation between imagination and reality, and meanwhile himself deconstructing the binary opposition of the two to give meanings to poems” (Liu, 1955, p. 56). Stevens believes that the mission of poets is to build a bridge linking the world of imagination and reality, and as Liu Sheng further analyzed that "this bridge is built on reality with transient sensory experience... On this bridge, poets can not only keep connections with reality, but also overlook unceasing life flow, which creates orders and meanings of reality” (Liu, 1955, p. 61). Thirteen Ways of Looking at A Blackbird ${ }^{1}$, one of Stevens' representative works, without exception profoundly explores the relation between imagination and reality, while its deep thoughts of deconstruction contained in it was barely noticed by people. Therefore, this study probes into how the poet deconstructs the binary opposition between imagination and reality since the time of Plato, aiming to create poems that make a better organized world.

\section{Deconstruction}

After Jacques Derrida published Structure, Sign, and Play in the Discourse of the Human Sciences in the autumn of 1966, the term deconstruction came out, and it has caused far-reaching influences on human thoughts

SHI Xuan, (Corresponding Author, First Author), Master of Arts, Huashang College Guangdong University of Finance and Economics.

1 All the citations of Thirteen ways of looking at a blackbird are from Wallace Stevens, 2009, Supreme Fiction Wallace Stevens' Poems and Essays. Zhang Dongbiao and Zhang Zao trans. Shanghai: East China Normal University. 
as well as literary criticism as a theory.

Tong Ming (2012) explains, "the primary significance of deconstruction lies in the unique analysis on the 'truth' concluded by classical thoughts of Plato tradition and 'knowledge' based on ontology. Deconstruction reveals the nature and problem of logocenticism on which the truth rely, and further advocates freeplay that intends to break the confinement of logocenticism to give an open interpretation, turning the enclosed structure or system into an open-ended signifying process” (p. 91). The center is composed of binary opposition, one of which is transcendental signified and refers to a point of presence. To put it simple, presence contains absolute, transcendental and unassailable semantic meanings, or truth. However, the opposite side of presence is absence, which is inferior to presence and usually negated and denied. In Chinese, presence stands for superiority, while absence inferiority. Nevertheless, Plato is the earliest originator of binary opposition. He advocates rationality, knowledge, philosophy and concepts while depreciate emotions, interpretation, literature and materials. In this case, the system of binary opposition separates what shouldn't have been polarized.

One more thing to be noted is that deconstruction aims not to destroy some system, but to alternate systems through analytical speculation and games of language. According to Tong Ming (2012), deconstruction, applying the art of wisdom, objects to binary opposition and believes negation should be avoided (p. 117).

\section{Wallace Stevens’ Views of Deconstruction}

Within the advancement of human thoughts, consciousness and science, there exists the binary oppostition between literature/art and science/ration. The former one stands for intuition, imagination, spirit, insight and subjectivity, while the latter one refers to ration, truth, material, facts, reality and objectivity. What Wallace Stevens does is to deconstruct the extreme polarization of imagination and reality. Chen Shuping (2010) points out that "Stevens thought that before rationality was built, people lived in imagination which contained strong perceptual performance and visions for human than rationality” (p. 155). That is to say, Stevens' purpose is to deconstruct the opposition of superior reality and belittled imagination to explore their relation in a new way.

As a poet, Wallace Stevens never ceases his thoughts toward philosophy in his long creation process. He even stated "feelings deconstruct the world, and minds reconstruct the world" (Poupard, 1984, p. 134). He sees the world through not experience and logic but only his eyes which see every part of the world objectively and closely and reorganize them into a new reality. This poem typically elucidates how he reorganizes the world through his reorganization by using imagination and then deconstructs the world he just built because he sees the world of reconstruction is only temporary, and he never seeks a final definition of his work as he ever stated that there is no certainty or any final meaning within a text, even within a long-existed text in the past, and all texts are a kind of reproduction. In fact, there always exists a hidden meaning lurking behind the text that has never been deciphered because of différance. Professor Wang (2018) even put forward the notion of "the death of author" and that there are multiple interpretations of one text, some of which may not be compatible with each other or even have nothing in common (p. 121).

\section{Reconstruction of the World}

Wallace Stevens emphasizes the function of imagination to a great extent, and he thinks "imagination is more about feelings of subjects toward physical objects than the talents of the subjects' inner construction" (Chen, 
2010, p. 153). Chen Shuping explains that "poets live in an age of spiritual poverty. According to Stevens, we live in the times of Darwin, not Plato, when the God died, all Greek Gods vanished, and religious believes collapsed. However, at this time, the mission of people is to fabricate a faith, seek truth for people live in the physical world and reflects the world through poetry (Chen, 2010, p. 13). Meanwhile, Stevens holds the view that truth is not important, and he can describe presence by using poetry and life experience (Chen, 2010, p. 13). In the poem Thirteen Ways of Looking at A Blackbird, Stevens observes a blackbird in thirteen ways, with the blackbird symbolizing imagination or imaginary thoughts with the purpose of reconstructing the whole world for all human kind.

In the first stanza, Among twenty snowy mountains, /The only moving thing /Was the eye of the blackbird. it describes a bleak winter covered with heavy snow, with everything remaining silent and tranquil, showing a scene full of fakeness, rigidity and deathly stillness. However, the remarkable vitality of the blackbird is rather distinct as the poet applies the contrast between black and white, stillness and action, and far and near images. Here the blackbird symbolizes imagination, and it is imagination that adds vigor and vitality to the world. Therefore, reality no longer rules imagination as it does in binary opposition, but is inferior to imagination instead in the viewpoint of Stevens.

In the second stanza, I was of three minds, /Like a tree/ In which there are three blackbirds. While some scholars think the three minds refer to id, ego, and superego from the perspective of psychology (Gu, 2013, p. 73), the three stands for ample amount of imagination, and tress is the way how the poems are manifested. Here, Stevens compares human brain to a tree, and the three blackbirds to his souls. However, what he differs from Wordsworth and other poets of traditional romanticism is that he stresses the importance of imagination as well as reality, which is fully embodied in his poems. Although this stanza is short and frankly written, it contains profound connotation of philosophy.

In the third stanza, The blackbird whirled in the autumn winds. /It was a small part of the pantomime. These two lines show the relationship of imagination and reality, and that of arts and the nature. Stevens assures not only that imagination is one part of the dull reality (pantomime), but also imagination's great function (whirling).

A man and a woman/ Are one. /A man and a woman and a blackbird /Are one (Stanza VI). I don not know which to prefer, /The beauty of inflections/ Or the beauty of innuendoes, /The blackbird whistling/ Or just after (Stanza V). These two stanzas distinctly point out the importance of blackbird which is the symbol of imagination. A man and a woman integrate into a human with physical flesh only, while the blackbird makes a complete human, a complete one with both physical being and mental being. Therefore, it is implied that the blackbird, or imagination is an indispensable part of the existence of complete human beings, especially the existence of people's spiritual world like faith or hope. No matter how it shows itself, as inflections or innuendoes, it is adored and favored by the poet.

Stanza VI, Icicles filled the long window/ With the barbaric glass. /The shadow of the blackbird/ Crossed it, to and fro. /The mood'Traced in the shadow/ An indecipherable cause. In this stanza, Wallace Stevens underlines people's different perception toward signifier and signified of everything in the world, for which people generate various understanding of the world. However, "the impact of ephemeral inspiration on poets is blurred and variable, showing the unconsciousness of creation and appreciation of written works, which happens to hold the similar view with the deconstruction of binary opposition in Saussure's theory of language signs” (Gu, 2013, p. 74). 
O thin men of Haddam, /Why do you imagine golden birds?/ Do you not see how the blackbird/ Walks around the feet/ Of the women about you? (Stanza VII). The golden birds suggest those who in Yeats' poem Sailing to Byzantium sing for the drowsy emperor, lords and ladies of Byzantium of what is past, or passing or to come. While Yeats extols the eternal beauty of arts in his poem, Wallace Stevens reminds people of the existence of blackbird, without which men are thin and weak, and what's more important, imagination is an indispensable part of construction of the world. It's still rather obvious that Stevens tries to deconstruct the binary opposition of imagination and reality to reconstruct human and the world by emphasizing the uniquely vital role of imagination.

In stanza VIII, VIIII, X, XI, Stevens in fact is trying to reconstruct a world where all the accents, rhythms and all sounds are noble as long as blackbird is involved; bawds of euphony is utterly refreshed and shocked when she catches the sight of blackbirds which brings her surprise and energy of life; and when he (in stanza XI) mistakenly sees the shadow of his coach as blackbirds, a fear pierced him, which gives readers a vivid image of people's feelings of fear when imagination is beneath reality or to be more specific, ruled by reality. Therefore, the poet wishes to smash the world that has been regularized, rationalized, conceptualized, and programmed and establish a new world. However, this is still within the logical frame of binary opposition, so he starts to deconstruct.

\section{Deconstruction}

Stanza XII tells us that as long as the river is flowing, the blackbird must be flying. That is to say, everything is moving, changing and developing, and nothing remains ever-lastingly unchanged. Just like the river never ceases flowing, imagination is developing and varying minute by minute. In the poet's eyes, imagination is a river of language that runs ceaselessly in people's consciousness and expresses the world and itself in a limited period of time. Similarly, our minds changes as constantly as weathers and seasons do.

It was evening all afternoon. /It was snowing/ And it was going to snow. /The blackbird sat/ In the cedar-limbs (Stanza XIII). This is the thirteenth way of looking at the blackbird, and in this way, the blackbird is static while the winter is dynamic with seemingly and permanently falling snows. This winter is the end of last year after spring, summer and autumn and the beginning of a new year, not like a still and bleak winter in the first stanza, but a energetic one with relentlessly flying snowflakes. Though winter signifies the cruelty of reality, Stevens does not only depict the vitality of the blackbird, which is turned into a still image in this stanza, but the vigor of winter, as a result of which, a world just reconstructed and completed by the poet is deconstructed. In this world, blackbird and the nature integrated together. This is how Stevens is different from traditional poets of romanticism. Although he insisted on the importance of imagination, he never intends to create an imaginary world without the foundation of reality without which, imagination would never derive from. At this time, Stevens realizes the limitation of imagination, so he deconstruct his binary opposition of superior imagination and inferior reality (or nature). However, deconstruction is not to negate something. Although the poem ends here, it is open-ended without giving a definite answer or solution, since Stevens knows that the physical world and imagination keep changing without a break, just like ever-changing winters. Everything awaits our explorations because there is no absolute truth or ruler forever.

In his Supreme Fiction Wallace Stevens’ Poems and Essay, Wallace Stevens ever put forward three 
functions of poetry. First, it must be abstract. Poets should extract reality from imagination after its abstraction, aiming to reveal the facts and truth about life and the world. Second, it contains thoughts of changing. Stevens objects to permanent truth. He believes that the only thing remain unchanged is change itself. Since the flowing river of new things and new experience never stops and poets should take the challenge of constantly changing world with creative imagination, and find temporary state of things in the world. Third, it must bring joy. The pleasure obtained when poets are connecting imagination and reality should be shared with readers. In this poem, changes permeate every stanza, for example, the changes of seasons, observing perspectives, light angles, and transformation of stillness and action, etc. (Liu, 1995, p. 60). During this process, there seemingly is a constant interaction between reality and imagination in Stevens poems. In this case, with the view of variability and mobility, Stevens can experience different aspects of the world from various perspectives, as a result of which, he could depict the diversity of nature and life and deconstruct the binary opposition of imagination and reality continuously.

\section{Conclusion}

Poets give discriminating attention to arts, imagination and reality when appreciating beauty, however, the functions of arts and imagination are raised to philosophical issues by Wallace Stevens. In his short poem Thirteen Ways of Looking at a Blackbird, he uses dynamic and static images such as silent snowy mountains, trees, flowing river, changing seasons etc. and build a world dominated by imagination. Nonetheless, he at last deconstructs the world he just built, which illustrates a process of reconstructing and deconstructing. As for the relation between imagination and reality, it is open-ended in this poem, leaving space for people and himself to explore further. For Wallace Stevens, imagination and reality is his never-endingly theme to be probed into and as the "poet of poets", he has gained himself honorable for the beautiful images, deep thoughts and profound connotations of him poems. As a poet, he is also a philosopher; as a philosopher, he is also a poet.

\section{References}

Chen, S. P. (2010). A study on the aesthetics of Wallace Stevens poetry. Wu Han: Central China Normal University.

Dong, M, (2012). Western literary criticism key word: Deconstruction. Foreign Literature, (5), 90-119.

Gu, J. (2013). An interpretation of Wallace Stevens philosophical poem Thirteen ways of looking at a blackbird. Short Stories, (17), 73-74.

Liu, S. (1995). Reality·imagination·poetry: A study on Wallace Stevens’ views on poetry. Foreign Literature Studies, (2), 56-61. Poupard, D. (1984). Twentieth century literary criticism (Vol. 12). Detroit, Michigan: Gale Research Company, Book Tower.

Stevens, W. (2009). Supreme fiction Wallace Stevens' poems and essays (D. B. Zhang and Z. Zhang, Trans.). Shanghai: East China Normal University.

Wang, X. F. (2018). From structuralism to Derrida's deconstruction. Journal of Liaoning University (Philosophy and Social Sciences), 46(1), 118-122.

Yin, L. J. (2009). A study on the interaction of reality and imagination in Wallace Stevens' poetry. Journal of Zhengzhou University (Social Science Edition), 42(4), 69-71. 